\title{
STUDY OF IMPACTS OF OIL SPILL ON THE SUNDARBANS MANGROVE FOREST OF BANGLADESH
}

\author{
ABDULLAH HARUN CHOWDHURY ${ }^{1}$ AND MD ALI AKBER \\ Environmental Science Discipline, Khulna University, Bangladesh
}

\begin{abstract}
Studies were carried out on the recent oil spill in the Sundarbans of Bangladesh to find out the immediate impacts on the ecosystem of the Sundarbans after oil spilling. More than $500 \mathrm{~km}^{2}$ areas out of the total study area have been affected seriously by the oil spill contamination on 9 December 2014. Recorded data of the physico-chemical conditions, oil content, productivity, diversity and abundance of phyto-zooplankton and benthos of water, and oil content in soil indicate that the water and soil of the Eastern part of the Sundarbans were polluted by the oil contamination. Results also indicate that seedlings, mangrove algae, eggs and hatchlings of commercially valuable fishes, mudskippers, mud crabs, snails, monitor lizards were affected due to oil spill. Regeneration of the Sundri trees; intertidal zone bird - 'Masked finfoot', common birds, fishing cat, otter, dolphins, crocodile would be affected due to the oil spill. Long term monitoring, in depth research and proper implementation of all rules and regulations are necessary to save the fragile ecosystem of the Sundarbans-the UNESCO declared world heritage site.
\end{abstract}

Key words: Oil spill, Sundarbans, Mangrove ecosystems, Impact

\section{Introduction}

The Sundarbans - the single largest tract mangrove forest is located in the South-West area of Bangladesh. Officially it is known as the 'Sundarbans Reserve Forest (SRF) and divided in West and East zones', whole forest covered an area of $3956 \mathrm{~km}^{2}$ mangrove forest lands and more than $1800 \mathrm{~km}^{2}$ water bodies (Hussain and Acharya 1994 and IUCN 2001). It is intersected by a network of tidal canals, creeks and rivers. This tidal forest is very rich with natural ecological resources especially floral and faunal diversity (IUCN 2001 and Chowdhury 2003). More than 500 thousand peoples are directly and indirectly depending on the Sundarbans for their livelihoods as well as socio-economic purposes (Biswas et al. 2007, Giri et al. 2007 and Uddin et al. 2013).

Considering the ecosystem functions and services of the SRF in both regional and global extent, it was declared as 'Ramsar site' in 1992 and 'World Heritage Site' in 1997 by UNESCO (FAO 2007). In 1999, the Department of Environment (DoE) of Bangladesh declared the SRF as 'Ecological Critical Area (ECA)'(DoE 2010) including $10 \mathrm{~km}$ buffer zone surrounding of the forest. The plant populations of the ecologically sensitive forestSundarbans area are being changed due to some environmental threats like macro and micro climatic changes, increasing of salinity in soil and water, natural calamity,

${ }^{1}$ Corresponding Author: aharunc_ku@yahoo.com 
land erosion, siltation of the river beds, decreasing of up streams fresh water flows etc. (Mannan 2010, Chowdhury 2011, Mannan et al. 2012 and Hossain 2014).

On 9 December 2014, an oil tanker carrying about 75000 gallons (350000 liters) of black-furnace oil was passing through the Shela river (inside the SRF east zone) while it slammed on another vessel and spilled the oil into the river. According to the authority of the Sundarbans forest department, floating black-furnace oil was being spread to the small creeks, canals and forest floors within twenty four hours due to tidal action; as a result black-furnace oil was deposited on the soil of inter tidal zones, forests floors, plants leaves, stems, floating fruits, roots and pneumatophores (breathing roots of mangrove plants) etc. The surfaces of the rivers, creeks and canals of that part of the SRF were being covered gradually by the black oil spills. Kingston (2002) observed that oil contamination in mangroves poses long-term impacts which can be measureable for decades after the event. According to Chowdhury and Zaman (2001 and 2002) and Bhuiyan (1983) oil contamination in the water body is responsible for changing the water quality and for decreasing the productivity, abundance of phytoplankton and zooplankton of a water body.

Under the circumstances, it was imperative to institute an investigation on the estimation of oil spill hazards and their impacts on the flora, fauna, soil, water and ecosystems of the Sundarbans. This study was conducted to find out the possible immediate impacts of oil spill on the ecological and biological conditions of the Sudarbans i.e. physico-chemical conditions of water and soil, population of plankton and benthos, status of flora and fauna.

\section{Materials and Methods}

Selection of study area: The study was conducted from 11 December 2014 to 25 December 2014 in 15 different locations $\left(22^{\circ} 22^{\prime} 15.47^{\prime \prime} \mathrm{N} 89^{\circ} 39^{\prime} 23.78^{\prime \prime} \mathrm{E}, 22^{\circ} 21^{\prime}\right.$ $51.23^{\prime \prime} \mathrm{N} 89^{\circ} 39^{\prime} 59.10^{\prime \prime} \mathrm{E}, 22^{\circ} 20^{\prime} 16.71^{\prime \prime} \mathrm{N} 89^{\circ} 40^{\prime} 47.55^{\prime \prime} \mathrm{E}, 22^{\circ} 20^{\prime} 46.93^{\prime \prime} \mathrm{N} 89^{\circ}$ $42^{\prime} 43.19^{\prime \prime} \mathrm{E}, 22^{\circ} 17^{\prime} 35.66^{\prime \prime} \mathrm{N} 89^{\circ} 31^{\prime} 14.27^{\prime \prime} \mathrm{E}, 22^{\circ} 17^{\prime} 47.49^{\prime \prime} \mathrm{N} 89^{\circ} 36^{\prime} 55.83^{\prime \prime} \mathrm{E}$,

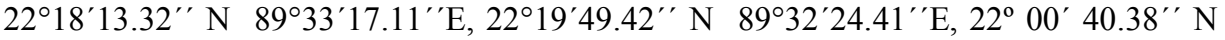
$89^{\circ} 44^{\prime} 38.75^{\prime \prime} \mathrm{E}, 22^{\circ} 01^{\prime} 29.89^{\prime \prime} \mathrm{N} 89^{\circ} 44^{\prime} 48.62^{\prime \prime} \mathrm{E}, 22^{\circ} 02^{\prime} 32.22^{\prime \prime} \mathrm{N} 89^{\circ} 45^{\prime}$ $00.73^{\prime \prime} \mathrm{E}, 22^{\circ} 07^{\prime} 52.91^{\prime \prime} \mathrm{N} 89^{\circ} 49^{\prime} 09.75^{\prime \prime} \mathrm{E}, 22^{\circ} 07^{\prime} 50.66^{\prime \prime} \mathrm{N} 89^{\circ} 47^{\prime} 17.67^{\prime \prime} \mathrm{E}, 22^{\circ}$ $08^{\prime} 14.09^{\prime \prime} \mathrm{N} 89^{\circ} 46^{\prime} 02.49^{\prime \prime} \mathrm{E}$ and $\left.22^{\circ} 13^{\prime} 28.54^{\prime \prime} \mathrm{N} 89^{\circ} 44^{\prime} 22.62^{\prime \prime} \mathrm{E}\right)$ of the eastern part of Sundarbans where the spilled oil was spread (Plate 1). Total study area was more than 1200 square kilometer. Samples were also collected from 3 different locations of

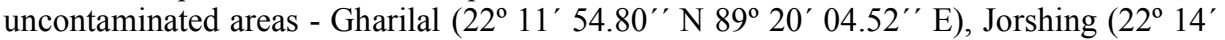
$\left.38.97^{\prime \prime} \mathrm{N} 89^{\circ} 21^{\prime} 34.70^{\prime \prime} \mathrm{E}\right)$ and Kalagachia $\left(22^{\circ} 12^{\prime} 22.78^{\prime \prime} \mathrm{N} 89^{\circ} 14^{\prime} 37.58^{\prime \prime} \mathrm{E}\right)$ of the western part of Sundarbans. The investigation tools used were site observations, spot and laboratory analyses. Samples were collected on 11, 13, 15, 17, 19, 21, 23 and 25 December 2014(48 hours interval sampling). The samples of the study were collected by using a country boat.

Collection of water sample and analysis: Water samples were collected from 10-25 cm depth by using a scale (Trivedy 1993) for physico-chemical analysis. A standard Secchi disc was used to measure the transparency of water while for water temperature a digital thermometer was used (Model No. 950). In situ measurements of total suspended solids 
(TSS), total dissolved solids (TDS), conductivity, salinity, pH and dissolved oxygen (DO) were carried out with the help of respective portable field meters. Titrimetric methods were used to determine free $\mathrm{CO}_{2}, \mathrm{CO}_{3}$ and $\mathrm{HCO}_{3}$ alkalinities (Welch 1948). $\mathrm{BOD}_{5}, \mathrm{COD}, \mathrm{NO}_{3} \mathrm{~N}$ and other chemical parameters were measured following APHA (1989). Calcium and magnesium were estimated following Mishra et al. (1992). Phosphate and silicate were measured following Gautam (1990). Primary productivity was measured by using dark-light bottle procedure (APHA 1989).

Soil sample collection and analysis: Oil contents of water and soil were measured by sulphuric acid, Petroleum ether and separating funnel procedure (APHA 1989 and Mishra et al. 1992). Shovels and large ladders were used to collect the soil samples according to Trivedy (1993). Soil quality was determined in the laboratory by following Jackson (1973) and Page et al. (1982). Plankton population was collected by using No. 20 silk bolting cloth (mesh size $0.076 \mathrm{~mm}$ ) and after collecting the plankton materials were transferred into the glass bottle and preserved permanently in Transeau's solution (Transeau 1951). Plankton abundance was counted by using Sedge-Wick Rafter Counting Chamber (APHA 1989) and expressed in unit/l whether it is an individual or a cell or a filament or part thereof. Plankton were identified by the help of relevant literatures (Edmondson 1966 and Tonapi 1980). Benthic macroinvertebrate samples were collected and studied by following SWAMP (2007) and APHA (1989). The populations of plants in field were measured by following quadrat method (Ambasht 1974). Standard observations and monitoring methods (Foot/Pug marks per quadrate area/ a standard area curve) were followed for different faunal study. Latitude and longitude were measured by using a hand GPS meter (model GARMIN GPSMAP ${ }^{\circledR} 78 \mathrm{~s}$ ). Statistical analysis among the different parameters was done by following Hoshmand (1998).

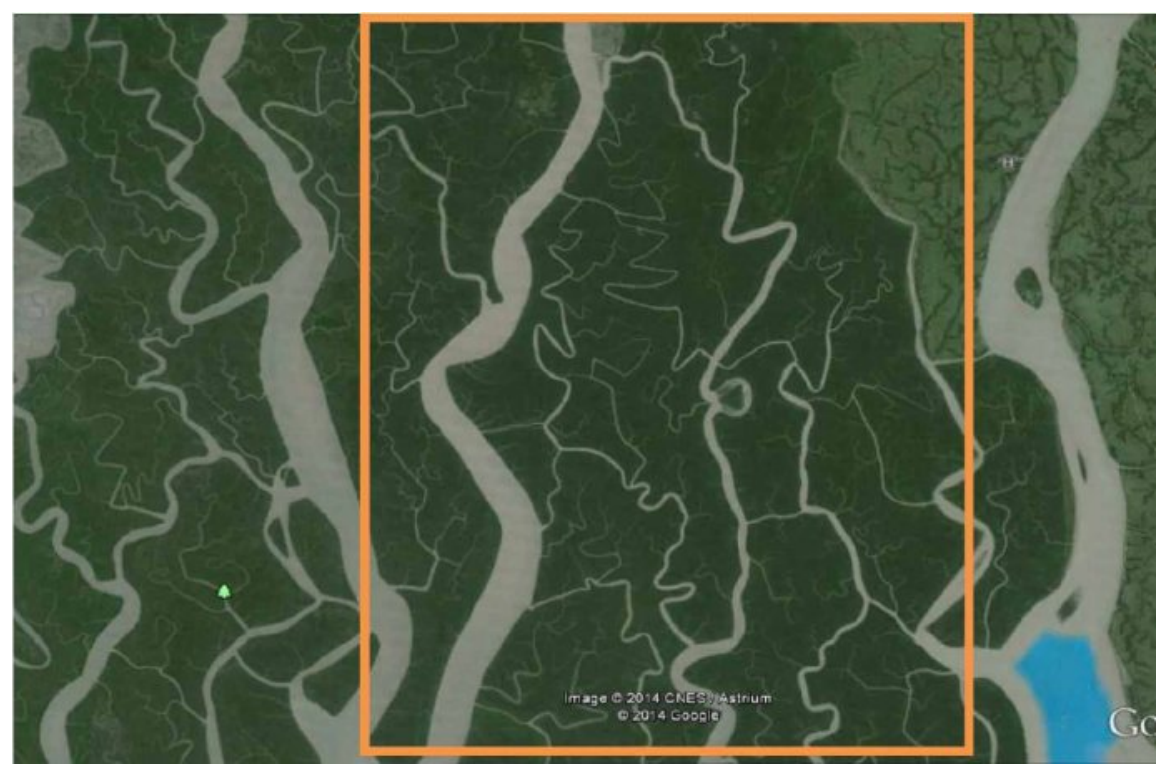

Plate 1. Oil contaminated study areas of the eastern SRF. 


\section{Results and Discussion}

Physico-chemical attributes of water and soil: Physico-chemical parameters and plankton abundance of water of oil contaminated and uncontaminated areas of the Sundarbans mangrove forest have been presented in Table 1 and physico-chemical conditions of soil of oil contaminated and uncontaminated areas have been presented in Table 2 .

The recorded data indicate that high content of oil $(995 \pm 429 \mathrm{mg} / \mathrm{l})$, total suspended solids $(999 \pm 447 \mathrm{mg} / \mathrm{l})$ and total hardness value $(2156 \pm 132 \mathrm{mg} / \mathrm{l})$ along with higher chemical oxygen demand (COD) value $(377 \pm 104 \mathrm{mg} / \mathrm{l})$ were present in the oil contaminated areas during study period. On the other hand, low transparency $(12 \pm 2 \mathrm{~cm})$ and productivity $(12 \pm 2 \mathrm{mg} / \mathrm{l})$ values, and poor abundance of phytoplankton (32 \pm 19 units/l) and zooplankton $(7 \pm 1.5$ units/1) were recorded in the oil contaminated areas of the Sundarbans (Eastern part of SRF). Whereas, the recoded data of the same study period of the uncontaminated areas of the Sundarbans (Western part of SRF) indicate that oil content was very poor $(8.4 \pm 0.9 \mathrm{mg} / \mathrm{l})$ than that of contaminated areas. The values of total suspended solids $(9.5 \pm 1.8 \mathrm{mg} / \mathrm{l})$, chemical oxygen demand $(69 \pm 8)$ and total hardness $(965 \pm 41 \mathrm{mg} / \mathrm{l})$ of uncontaminated areas were also very lower than those of contaminated areas of SRF. Similarly the values of transparency $(26 \pm 5 \mathrm{~cm})$ and productivity $(14 \pm 0.5$ $\mathrm{mg} / \mathrm{l})$, and abundance of phytoplankton ( $324 \pm 65$ units/l) and zooplankton (52 \pm 13 units/1) of the uncontaminated areas were much higher than those of oil contaminated areas of SRF. Oil content $(1080 \pm 420 \mathrm{mg} / \mathrm{kg}$ of 2 inch surface soil) of soil of intertidal zones of the oil contaminated areas was very high than oil content $(5.5 \pm 0.6 \mathrm{mg} / \mathrm{kg}$ of 2 inch surface soil) of uncontaminated areas. High values of oil, total suspended solids, chemical oxygen demand and total hardness; poor values of productivity and transparency; poor abundance of phytoplankton and zooplankton of water, and high content oil of soil indicate that the study areas of the eastern part of the Sundarbans reserve forest (SRF) had been affected by the oil spill. This finding has been supported by the studies of Chowdhury (2009 and 2011), Hossain and Chowdhury (2008), Rahaman et al. (2013) and Rahman et al. (2006, 2013 and 2014). They had recorded good transparency $(27 \pm 5 \mathrm{~cm})$, productivity $(17 \pm 0.8 \mathrm{mg} / \mathrm{l})$, phytoplankton $(407 \pm 53$ units/l) and zooplankton (59 \pm 14 units/1) abundance but low values of total suspended solids $(9.2 \pm 1.4 \mathrm{mg} / \mathrm{l})$, chemical oxygen demands $(63 \pm 5 \mathrm{mg} / \mathrm{l})$, total hardness $(946 \pm 53$ $\mathrm{mg} / \mathrm{l})$ and oil $(7.26 \pm 0.4 \mathrm{mg} / \mathrm{l}$ in water, $3.0 \pm 0.2 \mathrm{mg} / \mathrm{kg}$ of 2 inch surface soil) in their studies in the Sundarbans. 
Study of impacts of oil spill on the Sundarbans

Table 1. Physico-chemical and biological attributes of water of continental and un-continental areas.

\begin{tabular}{|c|c|c|c|c|c|c|c|c|c|}
\hline \multirow{2}{*}{ Parameter } & \multirow{2}{*}{ Unit } & \multicolumn{4}{|c|}{ Oil contaminated areas } & \multicolumn{4}{|c|}{ Uncontaminated areas } \\
\hline & & Mean & SD & Min & Max & Mean & SD & Min & Max \\
\hline Air temperature & ${ }^{\circ} \mathrm{C}$ & 22.1 & 1.8 & 19.4 & 25 & 22.2 & 1.8 & 19.6 & 26 \\
\hline Water temperature & ${ }^{\circ} \mathrm{C}$ & 22 & 0.5 & 20.1 & 23.5 & 24.8 & 0.8 & 22.2 & 26.6 \\
\hline Transparency & $\mathrm{cm}$ & 12 & 2 & 09 & 17 & 26 & 5 & 19 & 33 \\
\hline Total suspended solid & $\mathrm{mg} / \mathrm{l}$ & 999 & 447 & 317 & 1681 & 9.5 & 1.8 & 8.9 & 15.8 \\
\hline $\mathrm{pH}$ & & 7.4 & 0.2 & 7.4 & 7.7 & 8.0 & 0.5 & 7.8 & 8.8 \\
\hline Dissolved oxygen & $\mathrm{mg} / 1$ & 5.4 & 0.3 & 4.1 & 6.1 & 6.5 & 0.8 & 6.3 & 8.0 \\
\hline $\begin{array}{l}\text { Total dissolved } \\
\text { solid }\end{array}$ & $\mathrm{g} / 1$ & 21 & 1.3 & 17 & 25 & 16 & 5 & 10.8 & 23 \\
\hline Salinity & ppt & 12.9 & 1.5 & 12.7 & 14.3 & 13 & 1.1 & 12.8 & 14.5 \\
\hline Total hardness & $\mathrm{mg} / \mathrm{l}$ & 2156 & 132 & 1974 & 2232 & 965 & 41 & 940 & 1185 \\
\hline $\begin{array}{l}\text { Biological oxygen } \\
\text { demand }\left(\mathrm{BOD}_{5}\right)\end{array}$ & $\mathrm{mg} / \mathrm{l}$ & 2.8 & 0.5 & 2.5 & 3.9 & 1.9 & 0.3 & 1.4 & 2.4 \\
\hline $\begin{array}{l}\text { Chemical oxygen } \\
\text { demand }\end{array}$ & $\mathrm{mg} / \mathrm{l}$ & 377 & 104 & 275 & 598 & 69 & 8 & 56 & 81 \\
\hline $\begin{array}{l}\text { Carbon dioxide } \\
\left(\mathrm{CO}_{2} \text { alk. }\right)\end{array}$ & $\mathrm{mg} / \mathrm{l}$ & 25 & 6 & 16 & 36 & - & - & - & - \\
\hline Carbonate $\left(\mathrm{CO}_{3}\right.$ alk. $)$ & $\mathrm{mg} / \mathrm{l}$ & - & - & - & - & 29 & 10 & 24 & 39 \\
\hline Bicarbonate $\left(\mathrm{HCO}_{3}\right)$ & $\mathrm{mg} / \mathrm{l}$ & 131 & 23 & 115 & 157 & 112 & 16 & 97 & 132 \\
\hline $\begin{array}{l}\text { Nitrate as nitrogen } \\
\left(\mathrm{NO}_{3}-\mathrm{N}\right)\end{array}$ & $\mathrm{mg} / 1$ & 3.42 & 0.60 & 2.79 & 4.26 & 2.80 & 0.48 & 2.34 & 3.64 \\
\hline $\begin{array}{l}\text { Inorganic } \\
\text { phosphate }\left(\mathrm{PO}_{3}\right)\end{array}$ & $\mathrm{mg} / \mathrm{l}$ & 1.93 & 0.09 & 1.84 & 2.08 & 1.72 & 0.07 & 1.69 & 1.81 \\
\hline Silicate & $\mathrm{mg} / 1$ & 5.71 & 0.56 & 4.96 & 6.97 & 5.63 & 0.77 & 5.04 & 6.89 \\
\hline Calcium & $\mathrm{mg} / \mathrm{l}$ & 769 & 72 & 746 & 861 & 575 & 51 & 492 & 684 \\
\hline Magnesium & $\mathrm{mg} / 1$ & 489 & 63 & 477 & 585 & 315 & 75 & 230 & 426 \\
\hline Oil content & $\mathrm{mg} / \mathrm{l}$ & 995 & 429 & 295 & 1650 & 8.4 & 0.9 & 6.68 & 11.3 \\
\hline Productivity & $\mathrm{mg} / \mathrm{l}$ & 2.4 & 0.3 & 1.7 & 3.1 & 14 & 0.5 & 12.5 & 16.9 \\
\hline Phytoplankton & units/1 & 32 & 19 & 24 & 67 & 324 & 65 & 171 & 349 \\
\hline Zooplankton & units/1 & 7 & 1.5 & 6 & 10 & 52 & 13 & 45 & 71 \\
\hline
\end{tabular}

- = Not detected.

Table 2. Chemical attributes of soil of continental and un-continental areas.

\begin{tabular}{|c|c|c|c|c|c|c|c|c|c|}
\hline \multirow{2}{*}{ Parameter } & \multirow{2}{*}{ Unit } & \multicolumn{4}{|c|}{ Oil contaminated areas } & \multicolumn{4}{|c|}{ Uncontaminated areas } \\
\hline & & Mean & SD & Min & Max & Mean & $\mathrm{SD}$ & Min & Max \\
\hline $\mathrm{pH}$ & & 7.7 & 0.1 & 7.6 & 7.9 & 8.0 & 0.2 & 7.8 & 8.4 \\
\hline Salinity & ppt & 13.2 & 0.7 & 12.2 & 14.1 & 13.4 & 0.4 & 12.3 & 14.5 \\
\hline Total Nitrogen & $\%$ & 0.24 & 0.019 & 0.21 & 0.28 & 0.17 & 0.006 & 0.14 & 0.19 \\
\hline Phosphorus & $\mu \mathrm{g} / \mathrm{g}$ soil & 179 & 91 & 72 & 285 & 16 & 0.9 & 15 & 19 \\
\hline Sulfur & $\mu \mathrm{g} / \mathrm{g}$ soil & 104 & 9 & 98 & 115 & 94 & 4 & 85 & 105 \\
\hline Calcium & $\begin{array}{l}\text { meq/ } 100 \mathrm{~g} \\
\text { soil }\end{array}$ & 14.2 & 1.1 & 13.5 & 15.5 & 15 & 0.6 & 13.6 & 15.9 \\
\hline Magnesium & $\begin{array}{l}\text { meq/ } 100 \mathrm{~g} \\
\text { soil }\end{array}$ & 10.3 & 0.3 & 10 & 10.9 & 11.5 & 1.6 & 10.4 & 12.7 \\
\hline Potassium & $\begin{array}{l}\text { meq/ } 100 \mathrm{~g} \\
\text { soil }\end{array}$ & 1.53 & 0.10 & 1.45 & 1.69 & 1.62 & 0.39 & 1.45 & 1.98 \\
\hline Oil content & $\begin{array}{l}\mathrm{mg} / \mathrm{kg} \text { of } 2 \\
\text { inch surface } \\
\text { soil }\end{array}$ & $\begin{array}{r}108 \\
0\end{array}$ & 420 & 370 & 1690 & 5.5 & 0.6 & 4 & 8 \\
\hline
\end{tabular}


Chowdhury and Zaman (2001 and 2002) and Bhuiyan (1983) recorded in their studies that oil contamination in the water body was responsible for increasing of total suspended solids, COD and total hardness values of water and for decreasing of transparency, productivity and abundance of phytoplankton and zooplankton of water. The recorded data of the oil contaminated areas of the Sundarbans has been supported by the observations made by Chowdhury and Zaman (2001 and 2002) and Bhuiyan (1983).

More than $10 \mathrm{mg} / \mathrm{l}$ of oil in aquatic habitat can be lethal for the aquatic lives (APHA 1989). Higher content of oil was observed in the water and soil of intertidal zones of the oil contaminated areas of the Sundarbans (Tables 1 and 2). Therefore, the water and soil of the study areas of the eastern part of Sundarbans were polluted and affected by oil spilled on that time.

Status of Phytoplankton, zooplankton and benthos: Diversity and abundance of phytoplankton, zooplankton and benthos of oil contaminated and uncontaminated areas of the Sundarbans have been presented in Tables 3, 4 and 5 respectively. During the period of study total 45 phytoplankton (primary producer) species were recorded in uncontaminated areas of the Sundarbans (Western part of the SRF) and their abundance was found to vary from 171 to 349 units/l. Whereas, in the oil contaminated areas (Eastern part of the SRF), only 18 phytoplankton species were recorded and their abundance was found to vary from 24 to 67 units/1, which is very poor compared to that of the uncontaminated areas. Besides, the presence of Euglena sp. and Phacus sp. (pollution indicator) in oil contaminated areas also indicates pollution of the aquatic habitat of Sundarbans by spilled oil. Poor productivity values of the oil contaminated areas (Table 1) also indicate significant pollution of the water body by oil spill. Islam (1973), Chowdhury (2003 and 2011), Hossain and Chowdhury (2008) reported 44 phytoplankton species with 226 to 456 units/l abundance in different seasons from the aquatic ecosystems of the Sundarbans before oil contamination inside the Sundarbans. So it may be concluded that the different types of species and abundance of the phytoplankton (primary producer) were affected by the oil spill in aquatic ecosystems of the eastern side of Sundarbans. This result has been supported by the findings of Chowdhury and Zaman (2001) as they observed phytoplankton (primary producer) species diversity and abundance always being decreased by the oil pollution in the aquatic ecosystems. Phytoplankton abundance of the oil contaminated areas of the Sundarbans showed statistically significant negative correlation with oil content $(-0.803)$, TSS (-0.787), COD (-0.695) and total hardness (-0.848) values. 
Table 3. Abundance of phytoplankton (units/l) in the water of the Surndarbans.

\begin{tabular}{|c|c|c|c|c|c|c|}
\hline \multirow[t]{2}{*}{ Phytoplankton } & \multicolumn{2}{|c|}{$\begin{array}{c}\text { Oil contaminated } \\
\text { areas }\end{array}$} & \multicolumn{2}{|c|}{$\begin{array}{c}\text { Uncontaminated } \\
\text { areas }\end{array}$} & \multicolumn{2}{|c|}{ Reference data } \\
\hline & Min & $\operatorname{Max}$ & Min & Max & Min & $\operatorname{Max}$ \\
\hline \multicolumn{7}{|l|}{ Class: Cyanophyceae } \\
\hline $\begin{array}{l}\text { Calothrix } \\
\text { castellii }\end{array}$ & - & - & 1 & 4 & 3 & 7 \\
\hline Calothrix fusca & - & - & 5 & 10 & 6 & 12 \\
\hline $\begin{array}{l}\text { Lyngbya } \\
\text { corticicola }\end{array}$ & - & - & 2 & 4 & 5 & 9 \\
\hline $\begin{array}{l}\text { Lyngbya } \\
\text { confervoides }\end{array}$ & - & - & 3 & 5 & 4 & 10 \\
\hline Lyngbya lutea & - & 1 & 2 & 6 & 5 & 10 \\
\hline $\begin{array}{l}\text { Oscillatoria } \\
\text { amoena }\end{array}$ & - & - & 7 & 12 & 8 & 14 \\
\hline $\begin{array}{l}\text { Oscillatoria } \\
\text { limosa }\end{array}$ & 3 & 4 & 3 & 6 & 5 & 8 \\
\hline $\begin{array}{l}\text { Oscillatoria } \\
\text { princes }\end{array}$ & - & - & 1 & 3 & 3 & 5 \\
\hline $\begin{array}{l}\text { Oscillatoria } \\
\text { subbrevis }\end{array}$ & - & - & 7 & 11 & 7 & 14 \\
\hline $\begin{array}{l}\text { Oscillatoria } \\
\text { tenuis }\end{array}$ & 2 & 5 & 9 & 15 & 11 & 17 \\
\hline $\begin{array}{l}\text { Schizothrix } \\
\text { lamyi }\end{array}$ & - & - & 1 & 3 & 2 & 4 \\
\hline Spirulina major & 2 & 4 & 6 & 10 & 6 & 11 \\
\hline $\begin{array}{l}\text { Spirulina } \\
\text { subsalsa }\end{array}$ & - & - & 3 & 4 & 7 & 10 \\
\hline $\begin{array}{l}\text { Microcoleus } \\
\text { chthonoplastes }\end{array}$ & - & - & 2 & 5 & 3 & 7 \\
\hline \multicolumn{7}{|l|}{ Class: Chlorophyceae } \\
\hline $\begin{array}{l}\text { Chlorella } \\
\text { vulgaris }\end{array}$ & 2 & 4 & 4 & 9 & 5 & 8 \\
\hline $\begin{array}{l}\text { Closterium } \\
\text { costatum }\end{array}$ & - & - & 6 & 12 & 7 & 14 \\
\hline $\begin{array}{l}\text { Closterium } \\
\text { lagoense }\end{array}$ & - & - & 8 & 14 & 9 & 18 \\
\hline \multicolumn{7}{|l|}{ Class: Bacillariophyceae } \\
\hline $\begin{array}{l}\text { Chaetoceros } \\
\text { pendulus }\end{array}$ & - & - & 10 & 16 & 11 & 20 \\
\hline $\begin{array}{l}\text { Chaetoceros } \\
\text { socialis }\end{array}$ & - & - & 6 & 15 & 7 & 22 \\
\hline $\begin{array}{l}\text { Coscinodiscus } \\
\text { excentricus }\end{array}$ & - & - & 8 & 12 & 9 & 15 \\
\hline $\begin{array}{l}\text { Coscinodiscus } \\
\text { granii }\end{array}$ & - & - & 9 & 13 & 10 & 16 \\
\hline $\begin{array}{l}\text { Coscinodiscus } \\
\text { lineatus }\end{array}$ & - & - & 3 & 9 & 6 & 14 \\
\hline $\begin{array}{l}\text { Coscinodiscus } \\
\text { marginatus }\end{array}$ & 1 & 2 & 1 & 6 & 3 & 8 \\
\hline Coscinodiscus & - & - & 2 & 8 & 4 & 10 \\
\hline
\end{tabular}


Contd.

\begin{tabular}{|c|c|c|c|c|c|c|}
\hline \multirow[t]{2}{*}{ Phytoplankton } & \multicolumn{2}{|c|}{$\begin{array}{c}\text { Oil contaminated } \\
\text { areas }\end{array}$} & \multicolumn{2}{|c|}{$\begin{array}{c}\text { Uncontaminated } \\
\text { areas }\end{array}$} & \multicolumn{2}{|c|}{ Reference data } \\
\hline & Min & $\operatorname{Max}$ & Min & Max & Min & Max \\
\hline stellaris & & & & & & \\
\hline $\begin{array}{l}\text { Coscinodiscus } \\
\text { tumidus }\end{array}$ & - & - & 3 & 7 & 4 & 9 \\
\hline $\begin{array}{l}\text { Cyclotella } \\
\text { bodanica }\end{array}$ & - & - & 1 & 7 & 3 & 8 \\
\hline $\begin{array}{l}\text { Cymbella } \\
\text { gracilis }\end{array}$ & - & - & 2 & 6 & 4 & 8 \\
\hline $\begin{array}{l}\text { Gyrsigma } \\
\text { distortum }\end{array}$ & 1 & 2 & 2 & 4 & 3 & 7 \\
\hline $\begin{array}{l}\text { Melosira } \\
\text { arenaria }\end{array}$ & - & - & 8 & 13 & 9 & 16 \\
\hline $\begin{array}{l}\text { Melosira } \\
\text { granulate }\end{array}$ & 1 & 2 & 5 & 11 & 7 & 13 \\
\hline Melosira varians & - & - & 2 & 5 & 2 & 6 \\
\hline $\begin{array}{l}\text { Melosira } \\
\text { moniliformis }\end{array}$ & 1 & 3 & 3 & 8 & 3 & 10 \\
\hline Melosira sol & - & - & 2 & 3 & 3 & 5 \\
\hline $\begin{array}{l}\text { Melosira } \\
\text { undulate }\end{array}$ & 1 & 4 & 5 & 12 & 6 & 14 \\
\hline $\begin{array}{l}\text { Navicula } \\
\text { bacillum }\end{array}$ & 1 & 2 & 2 & 4 & 3 & 6 \\
\hline $\begin{array}{l}\text { Navicula } \\
\text { brekkaensis }\end{array}$ & - & - & 3 & 6 & 4 & 9 \\
\hline $\begin{array}{l}\text { Navicula } \\
\text { grimmei }\end{array}$ & - & 1 & 1 & 3 & 3 & 6 \\
\hline $\begin{array}{l}\text { Nitzschia } \\
\text { acicularis }\end{array}$ & - & - & 2 & 5 & 3 & 6 \\
\hline Nitzschia sigma & 2 & 3 & 4 & 7 & 4 & 8 \\
\hline $\begin{array}{l}\text { Surirella } \\
\text { fastuosa }\end{array}$ & - & - & 2 & 5 & 4 & 7 \\
\hline Surirell arobusta & 1 & 3 & 7 & 10 & 7 & 14 \\
\hline Synedra ulna & - & - & 2 & 8 & 3 & 10 \\
\hline Class: Euglenophyceae & & & & & & \\
\hline Euglenea sp. (2 sps.) & 4 & 10 & - & - & - & - \\
\hline Phacus sp. & 1 & 2 & - & - & - & - \\
\hline Class: Xanthophyceae & & & & & & \\
\hline $\begin{array}{l}\text { Centritractus } \\
\text { belanophorus }\end{array}$ & - & - & 3 & 6 & 4 & 8 \\
\hline Class: Dinophyceae & & & & & & \\
\hline Ceratium dens & 0 & 2 & 1 & 2 & 1 & 3 \\
\hline $\begin{array}{l}\text { Ceratium } \\
\text { extensum }\end{array}$ & 1 & 2 & 1 & 5 & - & - \\
\hline Total & 24 & 67 & 171 & 349 & 226 & 456 \\
\hline
\end{tabular}

- = Not detected. 
Table 4. Abundance of zooplankton (units/l) in the water of Sundarbans.

\begin{tabular}{|c|c|c|c|c|c|c|}
\hline \multirow[t]{2}{*}{ Zooplankton } & \multicolumn{2}{|c|}{$\begin{array}{l}\text { Oil contaminated } \\
\text { areas }\end{array}$} & \multicolumn{2}{|c|}{$\begin{array}{l}\text { Uncontaminated } \\
\text { areas }\end{array}$} & \multicolumn{2}{|c|}{$\begin{array}{c}\text { Reference } \\
\text { data }\end{array}$} \\
\hline & Min & Max & Min & Max & Min & Max \\
\hline Protozoa & & & & & & \\
\hline $\begin{array}{l}\text { Favella taraikaensis } \\
\text { Cladocera }\end{array}$ & 3 & 5 & - & - & - & - \\
\hline $\begin{array}{l}\text { Evadne tergestina } \\
\text { Copepoda }\end{array}$ & - & - & 2 & 5 & 4 & 6 \\
\hline $\begin{array}{l}\text { Calanus } \\
\text { helgolandicus }\end{array}$ & - & - & 6 & 8 & 7 & 9 \\
\hline Calanopia thompsoni & - & - & 6 & 10 & 8 & 11 \\
\hline Corycaeus flaccus & - & - & 7 & 13 & 9 & 12 \\
\hline Lucifer typus & - & - & 8 & 11 & 7 & 11 \\
\hline Microsetella rosea & 2 & 3 & 6 & 9 & 7 & 10 \\
\hline Oithona rigida & 1 & 2 & 8 & 12 & 9 & 14 \\
\hline Oncaea venusta & - & - & 2 & 3 & 2 & 4 \\
\hline Total & 6 & 10 & 45 & 71 & 53 & 77 \\
\hline
\end{tabular}

- = Not detected.

In the period of study only 2 zooplankton (primary consumer) species were recorded in the oil contaminated areas (eastern part of the SRF) and their abundance varied from 6 to 10 units/l, whereas 8 zooplankton species with 45 to 71 units/l abundance were recorded in the uncontaminated areas of the Sundarbans (western part of the SRF). Presence of Protozoa (pollution indicator) in oil contaminated areas of the Sundarbans also indicates the pollution of water by oil spill (Chowdhury and Zaman 2002). Islam (1974) and Chowdhury (2003 and 2011) recorded 8 zooplankton species in the aquatic ecosystems of the Sundarbans in different seasons and their abundance was found to vary from 53 to 77 units/1. So, it is clear that the zooplankton (primary consumer of water) diversity and abundance of the Sundarbans were decreased by the oil pollution. Chowdhury and Zaman (2002) also had recorded that most of the zooplankton species couldn't survive in the aquatic ecosystem except protozoa when oil content of water became more than 20 $\mathrm{mg} / \mathrm{l}$. Zooplankton abundance of the oil contaminated areas of the Sundarbans showed statistically significant negative correlation with oil content (-0.772), TSS (-0.772), COD $(-0.931)$ and total hardness $(-0.951)$ values. 
Table 5. Abundance of benthos in the water of Sundarbans.

\begin{tabular}{|c|c|c|c|}
\hline Benthos & $\begin{array}{r}\text { Oil contaminated } \\
\text { areas } \\
\end{array}$ & $\begin{array}{r}\text { Uncontaminated } \\
\text { areas } \\
\end{array}$ & $\begin{array}{r}\text { Reference } \\
\text { data } \\
\end{array}$ \\
\hline \multicolumn{4}{|l|}{ Order: Coleoptera } \\
\hline Dubiraphia vittata & - & ++ & ++ \\
\hline Promoresia tardella & - & + & ++ \\
\hline \multicolumn{4}{|l|}{ Order: Crustacea } \\
\hline Gammarus fasciatus & + & +++ & +++ \\
\hline $\begin{array}{l}\text { Palaemonetes } \\
\text { paludosus }\end{array}$ & - & ++ & ++ \\
\hline \multicolumn{4}{|l|}{ Order: Diptera } \\
\hline Ablabesmyia mallochi & + & +++ & +++ \\
\hline Cricotopus vierriensis & + & ++ & +++ \\
\hline $\begin{array}{l}\text { Cryptochironomus } \\
\text { fulvus }\end{array}$ & - & ++ & +++ \\
\hline Microtendipes pedellus & - & - & ++ \\
\hline Orthocladius dorenus & - & ++ & ++ \\
\hline Tribelos jucundum & - & - & ++ \\
\hline \multicolumn{4}{|l|}{ Order: Ephemeroptera } \\
\hline Acentrella alachua & - & - & ++ \\
\hline Baetis pluto & + & + & ++ \\
\hline Drunella lata & - & + & ++ \\
\hline Iswaeon anoka & + & ++ & +++ \\
\hline \multicolumn{4}{|l|}{ Order: Gastropoda } \\
\hline Cerithidea cingulata & - & ++ & ++ \\
\hline Helisoma anceps & - & + & ++ \\
\hline Laevapex fuscus & - & ++ & +++ \\
\hline $\begin{array}{l}\text { Micromenetus } \\
\text { dilatatus }\end{array}$ & - & ++ & +++ \\
\hline $\begin{array}{l}\text { Plicarcularia } \\
\text { leptospera }\end{array}$ & - & ++ & ++ \\
\hline Valvata cristata & - & ++ & +++ \\
\hline \multicolumn{4}{|l|}{ Order: Hemiptera } \\
\hline Belostoma sp. & - & +++ & +++ \\
\hline \multicolumn{4}{|l|}{ Order: Megaloptera } \\
\hline \multirow{2}{*}{\multicolumn{4}{|c|}{ Order: Odonata }} \\
\hline & & & \\
\hline Boyeria grafiana & + & ++ & ++ \\
\hline Epicordulia princeps & - & +++ & +++ \\
\hline \multicolumn{4}{|l|}{ Order: Oligochaeta } \\
\hline $\begin{array}{l}\text { Limnodrilu } \\
\text { shoffmeisteri }\end{array}$ & - & +++ & +++ \\
\hline Limnodrilus profundicola & - & + & +++ \\
\hline Tubifex heterochaetus & - & ++ & ++ \\
\hline Tubifex tubifex & - & +++ & +++ \\
\hline \multicolumn{4}{|l|}{ Order: Bivalvia } \\
\hline Corbicula fluminea & - & ++ & +++ \\
\hline Elliptio complanata & - & ++ & ++ \\
\hline \multicolumn{4}{|l|}{ Order: Plecoptera } \\
\hline Eccoptura xanthenes & - & ++ & ++ \\
\hline Haploperla brevis & - & - & ++ \\
\hline \multicolumn{4}{|l|}{ Order: Trichoptera } \\
\hline Micrasema bennetti & + & + & +++ \\
\hline Molanna blenda & - & ++ & ++ \\
\hline Total number of species present & 7 & 30 & 34 \\
\hline
\end{tabular}

‘+++' Very Common; ‘++' Common; '+'’ Rare; '-' Not detected 
Status of Flora and fauna: The recorded floral and faunal conditions of the oil contaminated areas and uncontaminated areas have been presented in Table 6 .

During the period of study it was observed that some flora and fauna were affected by oil pollution in many different ways (Table 6). Most of the seedlings of mangrove plants and 'saline water lily' of the intertidal zones were covered by oil and they were being decomposed (Table 6). Pneumatophores and most of the seeds of the Sundri plant were found to be oil covered; more than $90 \%$ embryos of the seeds were decomposed resulting the inhibition of their germination. Whereas, almost $100 \%$ embryos of the Sundri seeds were found in good condition in the uncontaminated areas (west SRF). In the Sundarbans, three species of macro red algae (Catenella sp.) were found to be attached with plant root and pneumatophores, and two species of a brown macro algae (Colpomenia sp.) were found to grow in small creeks as benthic form (Islam 1973 and Chowdhury 2003). Almost all of these algal flora were found in decomposed conditions in the oil affected area (Table 6).

Table 6. Floral and Faunal status of the oil contaminated and other areas of the Sundarbans.

\begin{tabular}{|c|c|c|c|c|c|}
\hline $\begin{array}{c}\text { Name of the } \\
\text { flora and Fauna }\end{array}$ & Units & $\begin{array}{c}\text { Oil } \\
\text { Contaminated } \\
\text { areas }\end{array}$ & $\begin{array}{c}\text { Uncontaminated } \\
\text { areas }\end{array}$ & $\begin{array}{c}\text { Previous } \\
\text { study } \\
\text { Before } \\
\text { Contaminat } \\
\text { ion } \\
\end{array}$ & Comments \\
\hline \multirow{2}{*}{$\begin{array}{l}\text { Seedling of } \\
\text { Plants } \\
\text { on intertidal } \\
\text { zones }\end{array}$} & \multirow[t]{2}{*}{ no. $/ \mathrm{m}^{2}$} & $2-3$ & \multirow[t]{2}{*}{$9-12$} & \multirow[t]{2}{*}{$12-18$} & \\
\hline & & $\begin{array}{l}\text { Most of the } \\
\text { seedlings were } \\
\text { covered by } \\
\text { black oil and } \\
\text { going to be } \\
\text { decomposed. }\end{array}$ & & & \\
\hline \multirow{2}{*}{$\begin{array}{l}\text { Saline water lily } \\
\text { on intertidal } \\
\text { zones }\end{array}$} & \multirow[t]{2}{*}{ no. $/ \mathrm{m}^{2}$} & - & $10-14$ & \multirow[t]{2}{*}{$12-22$} & \\
\hline & & $\begin{array}{l}\text { Plant bodies } \\
\text { were being } \\
\text { decomposed } \\
\text { due to oil spills. }\end{array}$ & & & \\
\hline \multirow{2}{*}{$\begin{array}{l}\text { Fruits/Seeds of } \\
\text { Sundri plants }\end{array}$} & \multirow[t]{2}{*}{ no. $/ \mathrm{m}^{2}$} & $9-14$ & \multirow[t]{2}{*}{$10-18$} & \multirow[t]{2}{*}{$10-19$} & \multirow[b]{2}{*}{$\begin{array}{l}\text { Embryo of } \\
\text { oil coated } \\
\text { seeds were } \\
\text { decompose } \\
\text { d as a result } \\
\text { seed would } \\
\text { not be } \\
\text { germinated }\end{array}$} \\
\hline & & $\begin{array}{l}95 \% \text { seeds were } \\
\text { covered by } \\
\text { black oil. }\end{array}$ & & & \\
\hline
\end{tabular}


Contd.

\begin{tabular}{|c|c|c|c|c|c|}
\hline $\begin{array}{c}\text { Name of the } \\
\text { flora and Fauna }\end{array}$ & Units & $\begin{array}{c}\text { Oil } \\
\text { Contaminated } \\
\text { areas }\end{array}$ & $\begin{array}{l}\text { Uncontaminated } \\
\text { areas }\end{array}$ & $\begin{array}{c}\text { Previous } \\
\text { study } \\
\text { Before } \\
\text { Contaminat } \\
\text { ion } \\
\end{array}$ & Comments \\
\hline $\begin{array}{l}\text { Pneumatophores } \\
\text { (Breathing } \\
\text { roots) of plants }\end{array}$ & no. $/ \mathrm{m}^{2}$ & $\begin{array}{l}>90 \% \\
\text { Pneumatophores } \\
\text { were covered by } \\
\text { black oil. }\end{array}$ & - & - & $\begin{array}{l}\text { Physiologic } \\
\text { al activities } \\
\text { of these } \\
\text { plants were } \\
\text { affected by } \\
\text { the oil } \\
\text { spills }\end{array}$ \\
\hline $\begin{array}{l}\text { Catenella sp. } \\
(3 \text { sps.)- a red } \\
\text { algae attached } \\
\text { with plant roots }\end{array}$ & no. $/ \mathrm{m}^{2}$ & $\begin{array}{l}>95 \% \text { were } \\
\text { decomposed } \\
\text { due to oil spills. }\end{array}$ & $\begin{array}{l}\text { Present in good } \\
\text { conditions }\end{array}$ & $\begin{array}{l}\text { Present in } \\
\text { good } \\
\text { conditions }\end{array}$ & $\begin{array}{l}\text { Worked as } \\
\text { primary } \\
\text { producer; } \\
\text { Source of } \\
\text { food and } \\
\text { nutrient of } \\
\text { the many } \\
\text { aquatic } \\
\text { animals }\end{array}$ \\
\hline $\begin{array}{l}\text { Colpomenia sp. } \\
\text { (2sps.)- a brown } \\
\text { macro algae } \\
\text { grows in small } \\
\text { creeks as } \\
\text { benthic form }\end{array}$ & no. $/ \mathrm{m}^{2}$ & $\begin{array}{l}\text { All were } \\
\text { decomposed } \\
\text { due to oil spills. }\end{array}$ & $\begin{array}{l}\text { Present in good } \\
\text { conditions }\end{array}$ & $\begin{array}{l}\text { Present in } \\
\text { good } \\
\text { conditions }\end{array}$ & $\begin{array}{l}\text { Worked as } \\
\text { primary } \\
\text { producer; } \\
\text { Source of } \\
\text { food and } \\
\text { nutrient of } \\
\text { the many } \\
\text { aquatic } \\
\text { animals }\end{array}$ \\
\hline $\begin{array}{l}\text { Eggs \& } \\
\text { hatchlings of } \\
\text { different fishes } \\
\text { i.e. Parshe, } \\
\text { Khursula, } \\
\text { Bagda, Harina } \\
\text { etc. }\end{array}$ & units/1 & $\begin{array}{l}\text { - } \\
\text { Totally absent } \\
\text { (But that was } \\
\text { the breeding } \\
\text { season of these } \\
\text { fishes) }\end{array}$ & 1500 to 2000 & $\begin{array}{c}2100 \text { to } \\
2400\end{array}$ & $\begin{array}{l}\text { Source of } \\
\text { natural and } \\
\text { cultivated } \\
\text { fish } \\
\text { production } \\
\text { in the } \\
\text { South-west } \\
\text { coastal } \\
\text { areas of } \\
\text { Bangladesh }\end{array}$ \\
\hline $\begin{array}{l}\text { Mudskippers - a } \\
\text { common } \\
\text { intertidal zone } \\
\text { fish }\end{array}$ & no. $/ \mathrm{m}^{2}$ & Totally absent & $2-4$ & $3-7$ & $\begin{array}{l}\text { Indicator of } \\
\text { mangrove } \\
\text { ecosystem } \\
\text { and used as } \\
\text { food by the } \\
\text { birds, } \\
\text { fishing cat, } \\
\text { otter, snake } \\
\text { and other } \\
\text { animals. }\end{array}$ \\
\hline
\end{tabular}


Contd.

\begin{tabular}{|c|c|c|c|c|c|}
\hline $\begin{array}{c}\text { Name of the } \\
\text { flora and Fauna }\end{array}$ & Units & $\begin{array}{c}\text { Oil } \\
\text { Contaminated } \\
\text { areas }\end{array}$ & $\begin{array}{l}\text { Uncontaminated } \\
\text { areas }\end{array}$ & $\begin{array}{c}\text { Previous } \\
\text { study } \\
\text { Before } \\
\text { Contaminat } \\
\text { ion } \\
\end{array}$ & Comments \\
\hline $\begin{array}{l}\text { Mud Crabs } \\
\text { (Kakra) (4sps.) } \\
\text { - a common } \\
\text { intertidal zone } \\
\text { Crustacea }\end{array}$ & no. $/ \mathrm{m}^{2}$ & $\begin{array}{c}- \\
\text { Totally absent } \\
\text { (Found dead } \\
\text { and } \\
\text { decomposed } \\
\text { bodies) }\end{array}$ & $2-4$ & $3-7$ & $\begin{array}{l}\text { Indicator of } \\
\text { mangrove } \\
\text { ecosystem } \\
\text { and } \\
\text { used as } \\
\text { food by the } \\
\text { birds, } \\
\text { crocodiles } \\
\text { and other } \\
\text { animals. }\end{array}$ \\
\hline $\begin{array}{l}\text { Snails (Shamuk) } \\
\text { (10 sps.) - a } \\
\text { common } \\
\text { intertidal zone } \\
\text { Mollusk }\end{array}$ & no. $/ \mathrm{m}^{2}$ & $\begin{array}{c}- \\
\text { Totally absent } \\
\text { (Found dead } \\
\text { and } \\
\text { decomposed } \\
\text { bodies) }\end{array}$ & $8-14$ & $9-17$ & $\begin{array}{l}\text { Indicator of } \\
\text { mangrove } \\
\text { ecosystem } \\
\text { and } \\
\text { used as } \\
\text { food by the } \\
\text { fishes, } \\
\text { birds, } \\
\text { crocodiles } \\
\text { and other } \\
\text { animals. }\end{array}$ \\
\hline $\begin{array}{l}\text { Fishes - } \\
\text { common fishes } \\
\text { of the river } \\
\text { Shela, canals, } \\
\text { creeks etc. }\end{array}$ & $\begin{array}{l}\text { No of } \\
\text { species }\end{array}$ & $10-14$ species & 27-33 species & $\begin{array}{l}31-43 \\
\text { species }\end{array}$ & $\begin{array}{l}\text { Major } \\
\text { aquatic } \\
\text { resource of } \\
\text { the } \\
\text { Sundarbans }\end{array}$ \\
\hline $\begin{array}{l}\text { Frogs ( } 2 \text { sps.) - } \\
\text { intertidal zone } \\
\text { of the river } \\
\text { Shela \& canals } \\
\text { are the habitats }\end{array}$ & $\begin{array}{l}\text { Study } \\
\text { period }\end{array}$ & $\begin{array}{c}\text { Six dead and } \\
\text { five black oil } \\
\text { covered Frogs } \\
\text { were observed } \\
\text { in the study } \\
\text { period }\end{array}$ & $\begin{array}{l}\text { Many Frogs were } \\
\text { observed in the } \\
\text { intertidal zones }\end{array}$ & $\begin{array}{l}\text { Unlimited } \\
\text { Frogs were } \\
\text { observed in } \\
\text { the study } \\
\text { area }\end{array}$ & $\begin{array}{l}\text { Common } \\
\text { Amphibian } \\
\text { of the } \\
\text { Sundarbans }\end{array}$ \\
\hline Snakes & $\begin{array}{l}\text { Study } \\
\text { period }\end{array}$ & $\begin{array}{l}4 \text { dead snakes } \\
\text { were observed } \\
\text { in the study } \\
\text { period }\end{array}$ & $\begin{array}{l}\text { Two Snakes were } \\
\text { observed due to } \\
\text { winter season }\end{array}$ & $\begin{array}{l}\text { Different } \\
\text { types of } \\
\text { Snakes } \\
\text { were } \\
\text { observed in } \\
\text { the } \\
\text { Sundarbans }\end{array}$ & $\begin{array}{l}\text { Vey } \\
\text { Common } \\
\text { Reptile of } \\
\text { the } \\
\text { Sundarbans }\end{array}$ \\
\hline $\begin{array}{l}\text { Monitor Lizards } \\
\text { (3 sps.) - }\end{array}$ & $\begin{array}{l}\text { Study } \\
\text { period }\end{array}$ & $\begin{array}{l}\text { One dead and } \\
\text { two black oil }\end{array}$ & $\begin{array}{l}16 \text { Monitor } \\
\text { Lizards of } 3\end{array}$ & $\begin{array}{l}\text { 21- } 27 \\
\text { Monitor }\end{array}$ & $\begin{array}{l}\text { Common } \\
\text { reptiles of }\end{array}$ \\
\hline
\end{tabular}


Contd.

\begin{tabular}{|c|c|c|c|c|c|}
\hline $\begin{array}{c}\text { Name of the } \\
\text { flora and Fauna }\end{array}$ & Units & $\begin{array}{c}\text { Oil } \\
\text { Contaminated } \\
\text { areas }\end{array}$ & $\begin{array}{c}\text { Uncontaminated } \\
\text { areas }\end{array}$ & $\begin{array}{c}\text { Previous } \\
\text { study } \\
\text { Before } \\
\text { Contaminat } \\
\text { ion } \\
\end{array}$ & Comments \\
\hline $\begin{array}{l}\text { intertidal zone } \\
\text { of the Shela } \\
\text { river \& canals } \\
\text { are the habitats }\end{array}$ & & $\begin{array}{l}\text { covered monitor } \\
\text { lizards were } \\
\text { observed in the } \\
\text { study period }\end{array}$ & $\begin{array}{c}\text { different species } \\
\text { were observed }\end{array}$ & $\begin{array}{l}\text { lizards of } 3 \\
\text { different } \\
\text { species } \\
\text { were } \\
\text { observed in } \\
\text { the study } \\
\text { area }\end{array}$ & $\begin{array}{l}\text { the } \\
\text { Sundarbans }\end{array}$ \\
\hline $\begin{array}{l}\text { Crocodile - } \\
\text { common animal } \\
\text { of the Shela } \\
\text { river and } \\
\text { connected } \\
\text { canals }\end{array}$ & $\begin{array}{l}\text { Per day/ } \\
\text { study } \\
\text { period }\end{array}$ & $\begin{array}{l}\text { Only oil coated } \\
\text { two crocodiles } \\
\text { were observed } \\
\text { in the study } \\
\text { period }\end{array}$ & $\begin{array}{c}2-4 \text { crocodiles } \\
\text { were observed in } \\
\text { a day }\end{array}$ & $\begin{array}{c}3-6 \\
\text { crocodiles } \\
\text { were } \\
\text { observed in } \\
\text { a day }\end{array}$ & $\begin{array}{l}\text { Threatened } \\
\text { species } \\
\text { and } \\
\text { Indicator of } \\
\text { the } \\
\text { mangrove } \\
\text { ecosystem }\end{array}$ \\
\hline $\begin{array}{l}\text { Intertidal Bird } \\
\text { (Masked } \\
\text { finfoot) - } \\
\text { intertidal zone } \\
\text { of the Shela } \\
\text { river \& canals } \\
\text { are habitat }\end{array}$ & $\begin{array}{l}\text { Study } \\
\text { period }\end{array}$ & $\begin{array}{l}\text { No Masked } \\
\text { finfoot bird was } \\
\text { observed in the } \\
\text { study period }\end{array}$ & $\begin{array}{l}\text { No Masked } \\
\text { finfoot was } \\
\text { observed }\end{array}$ & $\begin{array}{l}21 \text { Masked } \\
\text { finfoot } \\
\text { birds were } \\
\text { observed in } \\
\text { the study } \\
\text { area }\end{array}$ & $\begin{array}{l}\text { Worldwide } \\
\text { Threatened } \\
\text { species and } \\
\text { only the } \\
\text { mangrove } \\
\text { bird }\end{array}$ \\
\hline $\begin{array}{l}\text { Common Birds } \\
\text { (Heron, } \\
\text { Kingfisher etc. - } \\
\text { common animal } \\
\text { of the Shela } \\
\text { river and } \\
\text { connected } \\
\text { canals }\end{array}$ & $\begin{array}{l}\text { Study } \\
\text { period }\end{array}$ & $\begin{array}{l}\text { Only } 17 \text { oil } \\
\text { affected birds } \\
\text { (Heron) were } \\
\text { observed in the } \\
\text { study period }\end{array}$ & $\begin{array}{l}34 \text { types Birds } \\
\text { were observed }\end{array}$ & $\begin{array}{c}56 \text { types of } \\
\text { Birds were } \\
\text { observed }\end{array}$ & $\begin{array}{l}\text { Common } \\
\text { animals } \\
\text { of the } \\
\text { mangrove } \\
\text { ecosystem }\end{array}$ \\
\hline $\begin{array}{l}\text { Ban Morog } \\
\text { (Birds) - } \\
\text { common beside } \\
\text { the Shela river } \\
\text { and connected } \\
\text { canals }\end{array}$ & $\begin{array}{l}\text { Study } \\
\text { period }\end{array}$ & $\begin{array}{l}\text { No Ban Morog } \\
\text { was observed in } \\
\text { the study period }\end{array}$ & $\begin{array}{l}7 \text { Ban Morog } \\
\text { were observed }\end{array}$ & $\begin{array}{c}\text { Ban Morog } \\
\text { was } \\
\text { available }\end{array}$ & $\begin{array}{l}\text { Common } \\
\text { bird of the } \\
\text { mangrove } \\
\text { ecosystem }\end{array}$ \\
\hline $\begin{array}{l}\text { Migratory Birds } \\
\text { - intertidal zone } \\
\text { of the Shela } \\
\text { river \& canals } \\
\text { are habitats }\end{array}$ & $\begin{array}{l}\text { Study } \\
\text { period }\end{array}$ & $\begin{array}{l}\text { No Migratory } \\
\text { bird was } \\
\text { observed in the } \\
\text { study period }\end{array}$ & $\begin{array}{c}\text { Few migratory } \\
\text { birds was } \\
\text { observed }\end{array}$ & $\begin{array}{l}\text { Many } \\
\text { Migratory } \\
\text { birds were } \\
\text { observed in } \\
\text { the study } \\
\text { area }\end{array}$ & $\begin{array}{l}\text { The } \\
\text { Sundarbans } \\
\text { is the } \\
\text { habitat of } \\
\text { the } \\
\text { Migratory } \\
\text { birds; It } \\
\text { was the }\end{array}$ \\
\hline
\end{tabular}


Contd.

\begin{tabular}{|c|c|c|c|c|c|}
\hline $\begin{array}{c}\text { Name of the } \\
\text { flora and Fauna }\end{array}$ & Units & $\begin{array}{c}\text { Oil } \\
\text { Contaminated } \\
\text { areas }\end{array}$ & $\begin{array}{c}\text { Uncontaminated } \\
\text { areas }\end{array}$ & $\begin{array}{c}\text { Previous } \\
\text { study } \\
\text { Before } \\
\text { Contaminat } \\
\text { ion }\end{array}$ & Comments \\
\hline & & & & & $\begin{array}{l}\text { time of } \\
\text { migratory } \\
\text { birds }\end{array}$ \\
\hline Fishing cat & $\begin{array}{l}\text { Study } \\
\text { period }\end{array}$ & $\begin{array}{l}\text { Only one dead } \\
\text { Fishing cat was } \\
\text { observed in the } \\
\text { study period }\end{array}$ & $\begin{array}{l}\text { Foot mark of } \\
\text { fishing cat were } \\
\text { observed in the } \\
\text { intertidal zones }\end{array}$ & $\begin{array}{l}\text { Many foot } \\
\text { marks of } \\
\text { fishing cat } \\
\text { were } \\
\text { observed in } \\
\text { the study } \\
\text { area }\end{array}$ & $\begin{array}{l}\text { Common } \\
\text { animal of } \\
\text { the } \\
\text { Sundarbans }\end{array}$ \\
\hline $\begin{array}{l}\text { Otter - } \\
\text { intertidal zone } \\
\text { of the Shela } \\
\text { river \& canals } \\
\text { are the habitats }\end{array}$ & $\begin{array}{l}\text { Study } \\
\text { period }\end{array}$ & $\begin{array}{c}2 \text { dead and } 1 \\
\text { black oil } \\
\text { covered Otter } \\
\text { were observed } \\
\text { in the study } \\
\text { period }\end{array}$ & $\begin{array}{l}\text { Foot/ Pug Marks } \\
\text { of Otter were } \\
\text { observed in the } \\
\text { intertidal zones }\end{array}$ & $\begin{array}{l}\text { Unlimited } \\
\text { Foot Marks } \\
\text { of Otter } \\
\text { were } \\
\text { observed in } \\
\text { the study } \\
\text { area }\end{array}$ & $\begin{array}{l}\text { Threatened } \\
\text { animal in } \\
\text { the main } \\
\text { land but a } \\
\text { common } \\
\text { animal of } \\
\text { the } \\
\text { Sundarbans }\end{array}$ \\
\hline $\begin{array}{l}\text { Dolphins - } \\
\text { common animal } \\
\text { of the Shela } \\
\text { river and } \\
\text { connected } \\
\text { canals }\end{array}$ & no./hour & $\begin{array}{c}\text { No dolphin } \\
\text { observed in the } \\
\text { oil } \\
\text { contaminated } \\
\text { areas }\end{array}$ & $\begin{array}{c}5-10 \text { times } \\
\text { movements were } \\
\text { observed in a } \\
\text { hour }\end{array}$ & $\begin{array}{l}7-12 \text { times } \\
\text { movements } \\
\text { were } \\
\text { observed in } \\
\text { a hour }\end{array}$ & $\begin{array}{l}\text { Threatened } \\
\text { species } \\
\text { and } \\
\text { indicator of } \\
\text { the } \\
\text { mangrove } \\
\text { ecosystem }\end{array}$ \\
\hline $\begin{array}{l}\text { Deer - beside } \\
\text { the Shela river } \\
\& \text { connected } \\
\text { canals }\end{array}$ & $\begin{array}{l}\text { Study } \\
\text { period }\end{array}$ & $\begin{array}{l}\text { No deer was } \\
\text { observed in the } \\
\text { study period }\end{array}$ & $\begin{array}{l}\text { Deer was } \\
\text { Available in the } \\
\text { study area }\end{array}$ & $\begin{array}{l}\text { Unlimited } \\
\text { deer were } \\
\text { observed in } \\
\text { the study } \\
\text { area }\end{array}$ & $\begin{array}{l}\text { Common } \\
\text { Animal of } \\
\text { the } \\
\text { Sundarbans }\end{array}$ \\
\hline $\begin{array}{l}\text { Wild Boar - } \\
\text { beside the Shela } \\
\text { river \& } \\
\text { connected } \\
\text { canals }\end{array}$ & $\begin{array}{l}\text { Study } \\
\text { period }\end{array}$ & $\begin{array}{l}\text { No Wild Boar } \\
\text { was observed in } \\
\text { the study period }\end{array}$ & $\begin{array}{l}\text { Wild Boars were } \\
\text { observed in the } \\
\text { study area }\end{array}$ & $\begin{array}{l}\text { Unlimited } \\
\text { Wild Boars } \\
\text { were } \\
\text { observed }\end{array}$ & $\begin{array}{l}\text { A Common } \\
\text { Animal of } \\
\text { the } \\
\text { Sundarbans }\end{array}$ \\
\hline
\end{tabular}

'-' Not detected

During study period 10 to 14 species of fishes were recorded in the oil contaminated areas, but 27 to 33 fish species were recorded in the unpolluted areas (Table 6). No eggs and hatchlings of commercially valuable fishes like Parshe (Liza spp.), Khorsula (Mugli 
spp.), Bagda shrimp (Penaeus monodon) etc. were found in the oil polluted areas, although the time of the study was the breeding season for those fishes, whereas 1500 to 2000 units/l of eggs and hatchlings of those fishes were recorded in the unpolluted areas (West SRF). Chowdhury (2011) had recorded 2001 to 2400 units/l of eggs and hatchlings of these fishes in the Sundarbans. Present study indicates that the oil spill posed profound threat for the eggs and hatchlings of different fishes. During the period of study it was found that mudskippers, mud crabs, and snails were totally absent on the intertidal zones of oil polluted areas; frogs, snakes, monitor lizards, otter and fishing cat were found dead and oil coated in the oil contaminated areas, whereas these faunal species were in normal conditions in the unpolluted areas of the Sundarbans (Table 6). Seventeen oil affected birds (Heron) were observed in the oil affected areas in the study period but no migratory bird was seen in that time. In the period of study any dolphin, crocodile, Maskedfinfoot (worldwide vulnerable mangrove bird), wild boar and deer were not recorded in the oil contaminated river, canals, creeks etc. and their intertidal zones and char Islands. Chowdhury (2003, 2011) and IUCN (2001) had recorded dolphins, crocodile, Maskedfinfoot, migratory birds, wild boar, deer etc. in and around the river Shela and its connected canals and creeks.

The mangrove communities show striking zonation pattern as their spatial distribution is highly correlated with physico-chemical factors (Alongi 2002). Lewis (1983) and Kingston (2002) had mentioned that the fine grained aerobic sediments reduce the rate of microbial breakdown rate of oil. In addition, the burrowing activities of crustaceans can lead to persistent and high level contamination in the root zone (Lewis 1983). As a result, the long-term impacts are generally confined to community structure anomalies (Kingston 2002). Thus, it is evident that the oil spill in the Sundarbans mangrove has potential threat on its ecosystem.

Based on the data of the present investigation and conditions of the study areas like physico-chemical attributes of water and soil it may be concluded that floral and faunal status of the intertidal zones and the forest floor besides the river Shela and connected canals, creeks of the Sundarbans had been contaminated by the furnace oil. According to Islam (1982 and Islam 1997), Karim (1988), Hussain and Acharya (1994), Nazrul-Islam (1995), Jahan et al. (2000), IUCN (2001), Chowdhury (2003) and Hossain (2014) this areas were free from this type of oil pollution. Floral and faunal status indicate that primary producer, consumer and some aquatic animals and some plants and their habitats had been affected by the oil pollution. It is a natural habit of crocodile to prepare their hatchling house besides the rivers, canals and creeks during the month of April- May (IUCN 2001). But due to oil contamination besides the river, canals and creeks crocodiles may not be able to prepare their hatchling house in these areas to lay and hatch their eggs. As a result crocodile may migrate from their own habitats and face territory conflict and ultimately crocodile's population would be affected. 
More than $500 \mathrm{~km}^{2}$ areas out of the total study area (more than $1200 \mathrm{~km}^{2}$ ) had been affected seriously by the oil spills contamination (Plate 2). Regeneration of the Sundri trees, population, habit and habitats of mudskippers, mud crabs, snails, monitor lizards, intertidal zone birds (world endangered bird 'Masked finfoot'), common birds, fishing cat, otter, dolphins and crocodile were affected due to contamination of the oil spills hazards of $9^{\text {th }}$ December 2014.

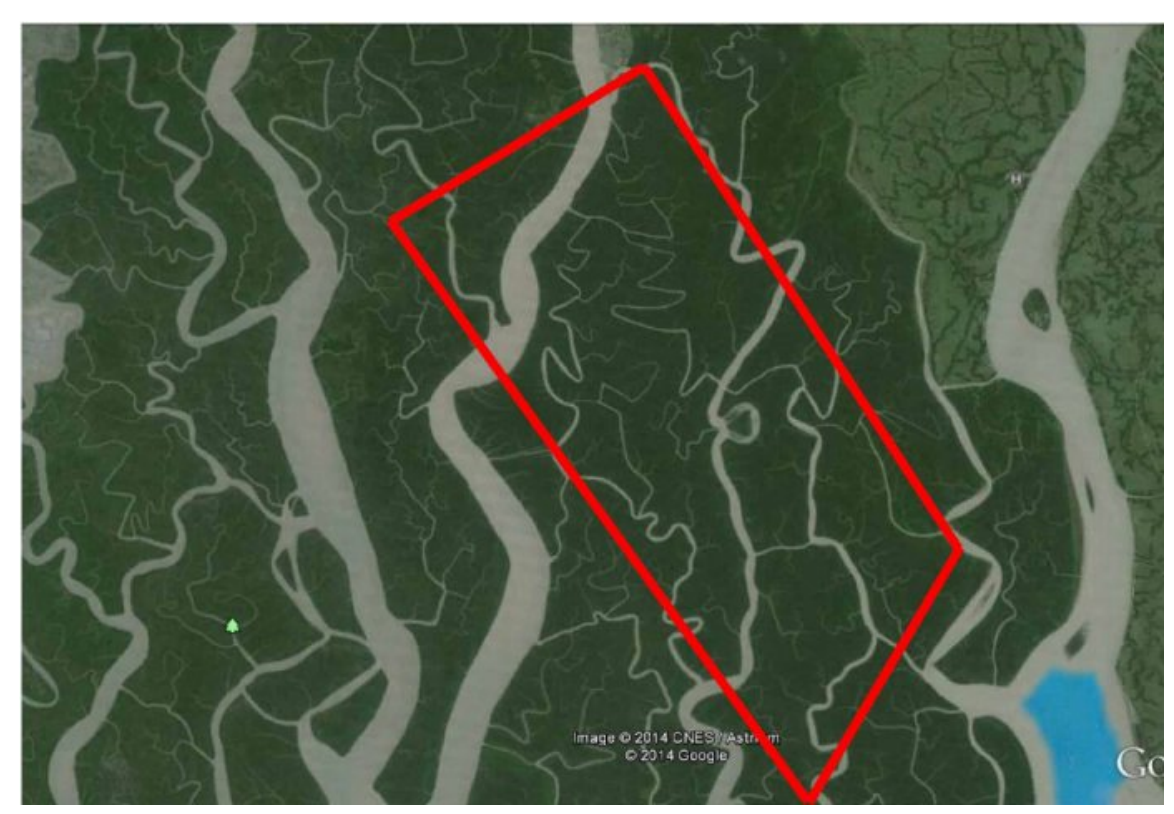

Plate 2. More oil contaminated areas of the eastern SRF.

So oil spill contention is a matter to be concerned and long term monitoring and in depth and multidimensional research are necessary to find out the detail information on the long term impact of oil pollution and self recovery capacity of ecosystem of the Sundarbans. Similarly the rules and regulations of international conventions like Ramsar, UNESCO Natural Heritage Site, Convention of Biological Diversity etc. must be implemented properly and a national and international commitment is necessary to stop all kinds of activities which may create this type of the problem for the fragile ecosystem of the Sundarbans.

\section{References}

Alongi, D. M. 2002. Present State and Future of the World's Mangrove Forests. Environmental Conservation 29(3):331-49. 
Ambasht, R.S. 1974. Plant Ecology. Students' Friends and Co., Varanasi, India. 261 pp.

APHA. 1989. Standard methods for the examination of water and waste water. American Public Health Association, Washington. 1125 pp.

Bhuiyan, A. M. 1983. Fresh Water and Brackish Water Pollution in Bangladesh. F.I.B. 1(3): 1-32.

Biswas, S. R., J. K. Choudhury, A. Nishat, and M. M. Rahman. 2007. Do invasive Plants Threaten the Sundarbans Mangrove Forest of Bangladesh? Forest Ecology and Management. 245(1-3):1-9.

Chowdhury, A. H. 2003. Glimpses of Flora and Fauna of the Sundarbans. Proceedings of the National Seminar on The Sundarbans, the Largest Mangrove Forest on the Earth: A World Heritage Site, (25-26 June 2003) Khulna University, Bangladesh. pp. 19 - 27.

Chowdhury, A. H. 2009. Impact of climate change on the rivers of Sundarbans. Proceedings of the Conference on Climate change and Bangladesh Development Strategy: Domestic Policy and International Cooperation (2 January 2009), Organized by BAPA, Dhaka, Bangladesh

Chowdhury, A. H. 2011. Environmental Threats on the Plant Resources of the Sundarbans-the World Heritage Site of Bangladesh (ICAER/O/103). Proceedings of International Conference on Advances in Ecological Research (19-21 December, 2011) M Ganga Singh University, Bikaner 334001 India. pp. 44 - 52.

Chowdhury, A. H. and M. Zaman. 2001. Physico-chemical characteristics and phytoplankton abundance of a water body polluted by oil-grease. Bangladesh J. Life. Sci. 13(1\&2): 197203.

Chowdhury, A. H. and M. Zaman. 2002. Impact of power plants effluent on the zooplankton. In: Proc. Conf. Industry \& Environment, 28-30, Dec. 1999 in Karad, India (ed. R. K Trivedy). pp. 201-207.

DoE. 2010. Fourth National Report to the Convention on Biological Diversity Biodiversity. Deparment of Environment, Ministry of Environment and Forests, Government of the People's Republic of Bangladesh.

Edmondson, W. T. (edi.). 1966. Fresh water Biology. John Wiley and Sons. INS. P 1-1248.

FAO. 2007. The World's Mangroves 1980-2005. Rome: FAO.

Gautam, A. 1990. Ecology and Pollution of Mountain Water. Ashish Publ. House, New Delhi, India. 209 pp.

Giri, C., B. Pengra, Z. Zhu, A. Singh, and L. L. Tieszen. 2007. Monitoring Mangrove Forest Dynamics of the Sundarbans in Bangladesh and India Using Multi-Temporal Satellite Data from 1973 to 2000. Estuarine, Coastal and Shelf Science 73(1-2):91-100.

Hoshmand, A. R. 1998. Statistical methods for environmental and agricultural sciences. CRR Press LLC, New York, USA. 439 pp.

Hossain, G. M. 2014. Ecosystem health status assessment of the Sundarbans mangrove forest in Bangladesh, Ph. D. thesis (unpubl.) Dept. of Botany, Jahangirnagar University, Savar, Dhaka.

Hossain, M. Z. and Chowdhury, A.H. 2008. Phytoplankton abundance in relation to physicochemical conditions of the Sundarbans estuary. J. Asiat. Soci. Bangladesh Sci. 34(2): 103-112.

Hussain, Z and G. Acharya. 1994. Mangrove of the Sundarbans, Volume 2: Bangladesh. IUCN, Bangkok, Thailand. 180 pp.

Islam, A. K. M. N. 1973. The algal flora of Sundarbans Mangrove forest. Bangladesh J. Bot. 2(2): 11-36. 
Islam, A. K. M. N. 1974. Study on the zooplankton of Sundarbans, Bangladesh. Bangladesh J. Zool. 2(2): 112-125.

Islam, A.K.M.N. 1982. Physiochemical properties of soils of Sundarbans Mangrove Forest. Proceedings of the Second National conference on forests, Dhaka, 50-52.

Islam G. M. J. 1997. Reports on the Malacofauna of the Sundarbans. M.Sc. Thesis(unpubl.). Dept. of Zoology, University of Rajshahi, Bangladesh.

IUCN. 2001. The Bangladesh Sundarbans: A Photoreal Sojourn. IUCN Bangladesh country office Dhaka, Bangladesh. 186 pp.

Jackson, M.L. 1973. Soil Chemical Analysis. Prentice-Hall of India (Pvt.) Ltd, New Delhi, India. $521 \mathrm{pp}$.

Jahan, M.S., G.M. Jaglul Islam and M. R. Rahman 2000. Molluscan biodiversity of Sundarbans, Bangladesh. Proceeding of the National Seminar on Coastal Environment and Energy Resources in Bangladesh, Organized by Environmental Sci. Discipline, Khulna University, Bangladesh 8-9 Dec. 1998.

Karim, A. 1988. Enironmental factors and the distribution of mangroves in Sundarbans with special reference to Heritera fomes. Buch-Ham. Ph.D. thesis (unpubl.) University of Calcutta. 200 pp.

Kingston, P. F. 2002. Long-Term Environmental Impact of Oil Spills. Spill Science and Technology Bulletin 7(02):53-61.

Lewis, R. R. 1983. Impact of Oil Spills on Mangrove Forests. In: Biology and Ecology of Mangrovves(ed. H. J. Teas. and W. Junk). pp. 171-83. The Hague.

Mannan, M. A. 2010. Impact of environmental hazards on the plant diversity of the Sundarbans Satkhira range. Ph.D. Thesis (unpubl.), Dept. Bot., Jahangirnagar University, Dhaka, Bangladesh. 157 pp.

Mannan, M. A., M. M. Rahman and A. H. Chowdhury. 2012. Plant population of Satkhira range of the Sundarban in relation to its physico-chemical conditions of soil. Jahan. Univ. J. Biol. Sci. 1(2): 17-24.

Mishra, S.N., R. Swarup and V.P. Jauhari. 1992. Encyclopaedia of Ecology, Environment and Pollution Control. Environmental Air and Water Analysis. Vol. 17. Ashish Publ. House, New Delhi, India. 136 pp.

Nazrul-Islam, A. K. M. 1995. Ecological conditions and species diversity in Sundarban mangrove forest community, Bangladesh M.A. Khan and I.A. Unger(eds.). Biology of salt tolerant plants 294-305 Book Grafers. 6BE International Drive Chelsea, Michigan. USA. 294$305 \mathrm{pp}$.

Page, A. L., R. H. Miller and D. R. Keeney. 1982. Methods of Soil Analysis (Part-2). American Society of Agronomy, Madison, Wisconsin, USA. 1143 pp.

Rahman, F., M. T. Rahman, M. S. Rahman and J. U. Ahmad. 2014. Organic Production of Koromjol, Passur River System of the Sundarbans, Bangladesh. Asian J. of Water, Env. and Pollution 11(1):95-103.

Rahman, M. M., M. T. Rahman, M. S. Rahaman, F. Rahman, J. U. Ahmad, B. Shakera and M. A. Halim. 2013. Water Quality of the World's Largest Mangrove Forest. Canadian Chem. Transactions 1(2): 141- 156.

Rahman, M. S., H. Ara and M.M. Islam. 2006. Determination of the total Hydrocarbon (Oil) Concentrations in the Shipping channel inside the Sundarbans Mangrove Forest of Bangladesh. KU Stud. (Special issue): 73-77. 
Rahaman, S. M. B., L. Sarder, M. S. Rahaman, A. K. Ghosh, S. K. Biswas, S.M. S. Siraj, K. A. Huq, A. F. M. Hasanuzzaman and S. S. Islam. 2013. Nutrient dynamics in the Sundarbans mangrove estuarine system of Bangladesh under different weather and tidal cycles. Ecological Processes 2(29): 1-13.

SWAMP. 2007. Standard Operating Procedures for Collecting Benthic Macroinvertebrate Samples and Associated Physical and Chemical Data for Ambient Bioassessments in California. Surface Water Ambient Monitoring Program. California Department of Fish and Game. pp 1-45.

Tonapi, G. T. 1980. Fresh Water Animals of India. Oxford and IBH Pub. Co. India. 342 pp.

Transeau, E. N. 1951. Zygnemaceae. Ohio State Uni. Press. Colu. USA. p.1-327.

Trivedy, R.K. 1993. River Pollution in India. Ashish Publ. House, New Delhi, India. 294 pp.

Uddin, M. S., E. de R. van Steveninck, M. Stuip, and M. A. R. Shah. 2013. Economic Valuation of Provisioning and Cultural Services of a Protected Mangrove Ecosystem: A Case Study on Sundarbans Reserve Forest, Bangladesh. Ecosystem Services 5:88-93.

Welch, P. S. 1948. Limnological Methods. McGraw Hill Book Company, New. York. 381 pp. 